\title{
A Systems Engineering Approach to Mentorship Program for Online Mili- tary and Veteran Engineering Students
}

\section{Dr. Reza Rahdar, Embry Riddle Aeronautical University}

Dr. Reza Rahdar, currently a full time faculty of the College of Aeronautics, have over 25 years of experience in systems design/development, and engineering systems that include telecommunication systems and networks, Radio communications, air defenses systems, avionics systems, and Airborne Warning and Control System (AWACS). Dr. Rahdar developed proficiency with systems engineering principles, process, and practices. He is an expert in taking systems from inception through design, development, and production. His skills are included but not limited to operations research, analytical/statistical analysis, trade studies, new product introduction including gates and design reviews processes, risk and opportunity management, reliability, availability \& maintainability, and safety analysis, and complex project management

\section{Dr. Ghazal Barari, Embry Riddle Aeronautical University}

Ghazal Barari received her PhD in mechanical engineering from University of Central Florida. Her research was focused on combustion modeling of promising biofuels in order to find a suitable substitute for fossil fuels. She started her career as a tenure track assistant professor in the college of engineering at Embry Riddle Aeronautical University at Prescott, Arizona where she was teaching mechanical and aerospace engineering Fluid mechanics and Thermodynamics courses. She joined ERAU-Worldwide College of Engineering as an assistant professor in 2018.

\section{Dr. Yuetong Lin, Embry-Riddle Aeronautical University - Worldwide}

Yuetong Lin received the Ph.D. degree in Systems and Industrial Engineering from the University of Arizona, Tucson, in 2005. He was with Indiana State University from 2005 to 2016, where he became associate professor of Electronics and Computer Engineering Technology, and the program coordinator for Computer Engineering Technology. He joined Embry-Riddle Aeronautical University, Worldwide in September 2016 as an associate professor in the Department of Engineering and Technology.

\section{Mr. Ryan Goyings, Embry-Riddle Aeronautical University - Worldwide}

I am currently an engineering instructor at Embry-Riddle Aeronautical University Worldwide. I'm currently living in Clarksville, Tennessee and been here since 2014. I'm originally from Paulding, Ohio, but served 24 years in the Army and so I've lived all over the continental United States - and two one-year tours at Camp Casey, Korea. I've also spent time in Iraq and Afghanistan.

My last assignment on active duty was at Fort Campbell, KY where I had the opportunity to serve as the Deputy Chief of Aviation Operations for the 101st Airborne (Air Assault) Division.

I received my Master's in Aeronautical Engineering from Purdue University in West Lafayette, Indiana. I graduated from the United States Military Academy (USMA) in 2001.

I taught in the Department of Civil and Mechanical Engineering at the United States Military Academy from 2011-2104. 


\title{
A Systems Engineering Approach to Mentorship Program for Online Military and Veteran Engineering Students
}

\begin{abstract}
Although online education has seen tremendous growth over the past decade, the lack of frequent and meaningful interactions between students and faculty has often been cited as one of the main obstacles for quality online educational experience and improving student learning outcomes. In the mean time, the flexibility and personalized learning opportunities offered by online modality are especially appealing to military students, but they have to overcome barriers in the online environment that are unique to their professional and private lives. In this work-in-progress paper, we will demonstrate the necessity of, and present a systems engineering approach to, developing an online mentorship program at one of the nation's leading online universities where about $60 \%$ of students are either veterans, members of the military or military dependents. The impact on students, especially active duty and veteran students will be reported later when assessment data is collected and analyzed.
\end{abstract}

\section{Introduction}

Online education is experiencing an explosive growth over the past decade. According to the latest report from the Education Department's National Center for Education Statistics [1], the number and proportion of college and university students taking classes online grew solidly by $5.7 \%$ in 2017, even as overall post-secondary enrollments fell by $0.5 \%$. Despite the tremendous growth, online education still faces significant challenges. Among them, the lack of frequent and meaningful interaction between students and faculty members has often been cited as the main obstacle for increasing the quality of online educational experience and improving student outcomes and satisfaction.

The flexibility and personalized learning opportunities offered by online modality are especially appealing to military students. The Education Department, using latest available statistics [2], found that $18 \%$ of military undergraduates took all of their courses online, compared with $12 \%$ of their nonmilitary peers. Among military graduate students, $41 \%$ attended fully online compared to $19 \%$ of nonmilitary graduate students. As one of the leading online universities in the country, Embry-Riddle Aeronautical University serves a vast student population in active duty service members and veterans. In the engineering and engineering technology programs of the Worldwide campus, active military and veterans account for 50\% and $20 \%$ of enrollment, respectively. In addition to the difficulties facing traditional and other non-traditional students, 
military students have to endure confusions and overcome barriers in the online environment that are unique to their professional and private lives. Helping this demographic earn college degrees and establish career paths not only has significant educational ramifications, but also serves a noble social cause for the country.

Among many touted solutions, mentoring has been shown to be a powerful method to overcome some of the major obstacles in online education and broader education community. Studies show that undergraduate students who are mentored tend to have higher GPAs, higher retention rates, and more units completed per semester as compared to their un-mentored colleagues [3].

It is in this background that the College of Aeronautics at Embry Riddle Aeronautical University has developed and launched a mentorship program aimed at helping online engineering and engineering technology students, in particular military and veterans succeed not only within, but also beyond the academic programs.

\section{Mentorship and Online Mentoring}

Mentoring has established itself as an effective strategy in addressing key issues and problems currently facing colleges and universities [4]. Mentorship is a relationship between a mentor and a mentee for informal transmission of knowledge, social capital, and the psychosocial support perceived by the recipient as relevant to work, career, or professional development [5]. In higher education, mentorship is often credited for providing an example and guide to the world in and beyond the student's educational journey, enhancing student's affinity to the program, College, and University, and enabling a greater persistence toward graduation goals [6]-[8]. Due to the prevalence and diversity of formal and informal mentoring programs and practices at postsecondary institutions, relevant theories and frameworks for effective mentoring have been developed and tested over the years. Crisp, Baker, Griffin, et al. [9] provide an updated synthesis of the undergraduate mentoring scholarship to address four specific questions: $a$ ) to identify and understand how empirical knowledge and theory have advanced; $b$ ) to identify and provide clarity about the characteristics that serve to meaningfully distinguish mentoring relationships and programmatic efforts; $c$ ) to integrate theory and research in a way that could provide tentative hypotheses regarding the relationship between the various characteristics and outcomes of mentoring; and $d$ ) to offer evidence-based practices for the administration of formal mentoring programs.

There is an important distinction between academic advisor and mentor. An advisor is responsible for providing information on degree requirements and guidance for students to complete a degree plan. A mentor, on the other hand is a positive role model who can guide and motivate student professionally. A mentor can provide resources and tools that will stimulate engagement in discussions about intellectual issues that will increase student's aspiration to achieve a higher level.

With the growth of online education, mentoring starts to take the same platform and relies on many of the same infrastructures. There have been numerous reports on online mentoring practice. For example, in [10], the effectiveness of a one-year online mentoring program for girls in STEM is studied. Mentee and mentor communicate with one another and with other program participants via email, online chat, and forums. The treatment-group participants show greater 
levels of desirable short-term and long-term developments. In [11], the authors present distributed mentoring, an online mentoring style inspired by the theory of distributed cognition. Seven key attributes that distinguish distributed mentoring from traditional, offline forms of mentoring are identified: aggregation, accretion, acceleration, abundance, availability, asynchronicity, and affect. Dhorne, Deflandre, Bernaert, et al. [12] show how mentoring is used to motivate learners to improve MOOCS course completion rates. The paper presents the approach to enhance coaching efficiency together with new teaching pedagogy. In [13], [14], Nuankaew and Temdee propose an online mentoring model that identifies mentor and mentee based on compatible different attributes.

However, online mentoring theories or frameworks are still in the early stage of development. The commonly used tools for online mentoring are email and weekly meetings between mentors and mentees. While acknowledging that the development of online mentorship Program has been a much more complex enterprise than a face-to-face equivalent program, Reali, Tancredi, and Mizukami argue that it still "promoted the establishment of professional and affective bonds among the participants, the broadening of professional knowledge, the mastery of online adult education technologies, and the participants' professional growth" [15].

\section{Online Mentorship Program: A Systems Engineering Approach}

In this paper, we will treat developing mentorship program as a process that harnesses systems engineering doctrines. As per INCOSE definition, the systems approach is defined as a means of identifying and understanding complex problems and opportunities, synthesizing possible alternatives, analyzing and selecting the best alternative, implementing and approving a solution, and deploying, using and sustaining engineered system solutions.

Identify stakeholders The success of the systems engineering approach relies on active participation of stakeholders in the entire systems development life-cycle. Therefore, the first step in the mentorship program development process starts with identification of stakeholders, which we have shown in Table 1.

Define needs and requirements Identifying and understanding the stakeholders' needs are essential to developing functional system, and in our case, mentorship program. This process will deter issues involving process improvement that could occur when total program is not kept in mind in achieving the purpose and/or goals.

Because military and veteran students are a key group of stakeholders, to build effective mentoring we need to recognize the unique circumstances in their professional lives that may cause additional disruptions in their online education. Some of the major challenges that these students face include:

- Deployment and re-assignments. There are many cases that students have been relocated (even oversea or the area with limited access to internet) during their terms of study.

- Budget allowance for the active duty and veterans is constantly changing. This change will limit the number of courses they can take. 


\begin{tabular}{|c|c|c|c|}
\hline Stakeholder & $\begin{array}{l}\text { Passive/Active } \\
\text { Stakeholder? }\end{array}$ & $\begin{array}{l}\text { Stakeholder } \\
\text { Role/Description }\end{array}$ & Outcomes and Benefits \\
\hline Mentor & Active & $\begin{array}{l}\text { Leadership. He or She } \\
\text { should play a role of } \\
\text { trusted advisor and be } \\
\text { able to share/transfer ex- } \\
\text { perience, knowledge, and } \\
\text { wisdom. Be a model and } \\
\text { set goals and objective }\end{array}$ & $\begin{array}{l}\text { Establish a trusted relation- } \\
\text { ship with open communica- } \\
\text { tion that will help mentee } \\
\text { toward achieving his/her } \\
\text { goals }\end{array}$ \\
\hline Mentee & Active & $\begin{array}{l}\text { Commitment to active par- } \\
\text { ticipation. He or she should } \\
\text { take their responsibilities } \\
\text { seriously and participate in } \\
\text { assigned/agreed activities }\end{array}$ & $\begin{array}{l}\text { Develop a roadmap for suc- } \\
\text { cess. Create channels to } \\
\text { receive and provide feed- } \\
\text { backs and recommenda- } \\
\text { tions }\end{array}$ \\
\hline $\begin{array}{l}\text { ERAU } \\
\text { COA }\end{array}$ & Active & $\begin{array}{l}\text { Sponsor the program. } \\
\text { Make it part of curriculum }\end{array}$ & $\begin{array}{l}\text { A supported partnership } \\
\text { program (pipeline) be- } \\
\text { tween faculty (mentor) and } \\
\text { students (mentee) that will } \\
\text { increase students take rate } \\
\text { and get students through } \\
\text { the entire pipeline }\end{array}$ \\
\hline $\begin{array}{l}\text { ERAU } \\
\text { Facilitators }\end{array}$ & Passive & $\begin{array}{l}\text { Create interactive intranet } \\
\text { site and make it visible to } \\
\text { all students. Provide and } \\
\text { support required means on } \\
\text { communication }\end{array}$ & $\begin{array}{l}\text { Ease of communication } \\
\text { and participation through } \\
\text { pipeline; mentor/mentee } \\
\text { communication }\end{array}$ \\
\hline $\begin{array}{l}\text { Active } \\
\text { Duty }\end{array}$ & Active/passive & $\begin{array}{l}\text { Support student in their } \\
\text { financial issue and allow } \\
\text { them to register in courses }\end{array}$ & $\begin{array}{l}\text { Allocate (availability) ap- } \\
\text { propriate fund for those } \\
\text { who are pursuing a suc- } \\
\text { cessful degree. Also, let } \\
\text { student participate in their } \\
\text { degree programs }\end{array}$ \\
\hline Veteran & Active & $\begin{array}{l}\text { Allocate and/or request for } \\
\text { approved funding }\end{array}$ & $\begin{array}{l}\text { Available funding towards } \\
\text { completion of their degree } \\
\text { programs }\end{array}$ \\
\hline $\begin{array}{l}\text { Family } \\
\text { (Mentee) }\end{array}$ & Passive & $\begin{array}{l}\text { Support (spiritually and fi- } \\
\text { nancially) and release some } \\
\text { time for study }\end{array}$ & $\begin{array}{l}\text { Ease of mind and backup } \\
\text { support to continue their } \\
\text { journey }\end{array}$ \\
\hline
\end{tabular}

Table 1: Mentorship Program Stakeholders 
- Life change caused by duty in war zone. Injured active duty members may not be able to continue to work.

A successful mentorship program requires defined and vetted problem statements. There are specific difficulties, such as physical distances, working on silo, or lack of interrelationship, that may be addressed by adding targeted services in the mentorship program. However, we have decided, based on inputs from stakeholders, that in current stage the mentoring initiative should focus on keeping students on track towards degree completion and more specifically, creating support structures to improve student take rate, retention rate, and graduation rate.

Table 2 shows the student headcounts for the three engineering and engineering technology programs that will be the main beneficiary of the mentorship effort. It is clear that the newly launched ABET-accredited B.S. in Engineering houses the majority of the students. While strong freshman and sophomore classes are often a good indicator of a healthy program, they also present a huge challenge for retention.

\begin{tabular}{c|c|c|c}
\hline $\begin{array}{c}\text { Degree } \\
\text { Program }\end{array}$ & AS Engineering & BS Engineering & BS Eng. Tech. \\
$\begin{array}{c}\text { Academic } \\
\text { Standing }\end{array}$ & 270 & 569 & 12 \\
\hline Freshman & 40 & 235 & 48 \\
\hline Sophomore & 10 & 66 & 137 \\
\hline Junior & N/A & 20 & 150 \\
\hline Senior & 320 & 924 & 358 \\
\hline Total & & &
\end{tabular}

Table 2: Student Headcounts

Historically, the undergraduate retention rates at ERAU have been low especially among active duty and veteran students. One key indicator for retention is the take rate. As shown in Table 3, the take rate for students who entered engineering program as freshmen and continued in BSE/BSET degrees between Fall 2016 and Spring 2019 ranged between 2.99 to 5.55 courses per year. There is clearly a upward trend for take rate as students move from underclassmen to upperclassmen. However, the available data from the university shows the take rate for active duty and veteran students, the largest demographic at ERAU, averaged only between 2.6 to 3.82 courses per year. Although the rate goes up when students move to upper class, it still remains low for military freshman and sophomore, and is lower than that of their civilian counterparts.

The University and College have made improving student take a priority in the strategic goal of student success. The mentoring team also believes raising take rate benefits all stakeholders of the program. For students, it means keeping them on pace towards degree completion; for department, it means healthy pipeline for program continuity; for school, it means good retention and graduation rates. The disparity between under- and upperclassmen however, indicates that 


\begin{tabular}{c|c|c|c}
\hline $\begin{array}{c}\text { Degree } \\
\text { Academic } \\
\text { Standing }\end{array}$ & AS Engineering & BS Engineering & BS Eng. Tech. \\
\hline Freshman & 2.57 & 3.08 & 3.17 \\
\hline Sophomore & 4.23 & 5.36 & 3.98 \\
\hline Junior & 9.30 & 8.23 & 5.55 \\
\hline Senior & N/A & 12.25 & 7.83 \\
\hline Average & 2.99 & 7.23 & 3.83 \\
\hline
\end{tabular}

Table 3: Student Take Rate

mentoring effort should be skewed towards freshmen and sophomores for improving take rate purpose, and focus on life long learning and career development for juniors and seniors.

Mentorship Program Design and Implementations. Mentoring program is developed in collaboration with administrative staff, academic support staff and leadership team. To better serve and relate to military beneficiaries, the department has hired specifically a full-time faculty with service background who will be the lead mentor for active duty and veteran mentees. The design, development and implementation stage of the project consists of the following phases.

- Phase 1: Program Development

- Explore methods to reach students

- Develop website and video

- Develop virtual career fair

- Lessons learned

- Phase 2: Launch

- Launch website and go live

- Register mentees

- Assign mentees to mentors

- Phase 3: Monitor and Evaluate

- Build mentor/mentee relationship

- Monitor progress; monthly/quarterly reports

- Evaluate and improve

In Phase 2, the performance of students at freshmen and sophomore level will be reviewed at least once a year. The students with below expectation take rate will be identified and registered into 
mentorship program and assigned to a mentor.

Students in the mentorship program have access to the following resources:

- Faculty/staff mentoring teams regarding their academic and personal goals

- A learning community where they can interact with a cohort of their peers sharing similar academic and non-academic experiences

- Preferred access to tutoring from COA's Virtual Center for Communication (VECTOR)

- Personal assistance in developing a portfolio of evidence to demonstrate that they have accrued top skills desired by potential employees

- Participation in networking events with industry professionals and ERAU alumni

\section{Conclusion}

In this work-in-progress paper, we present an online mentoring program that is developed based on systems engineering doctrines. The program is aimed at assisting constituents pursuing online engineering and technology degrees, especially active military and veterans who comprise a significant portion of ERAU student body. With the support structures in place, the mentoring program's success will be mainly measured, at the current stage, by student take rate. In the mean time, we will observe the following key factors to assess the program status after its launch:

- Sustain a steady mentor-mentee relationship. This means focusing on one or more of the following characteristics: resilience self-organization, and hierarchy.

- Focus on the mentor and mentee's needs - two-way communication. Mentor should look to improve the mentee's prospects while respecting the his/her personal life circumstances and perspective.

- Pursue and use help and support from facilitators and program staff.

\section{References}

[1] S. A. Ginder, J. E. Kelly-Reid, and F. B. Mann, "Enrollment and employees in postsecondary institutions, fall 2017; and financial statistics and academic libraries, fiscal year 2017”, U.S. DEPARTMENT OF EDUCATION, Tech. Rep., 2019.

[2] A. Radford, A. Bentz, R. Dekker, and J. Paslov, "After the post-9/11 GI bill: A profile of military service members and veterans enrolled in undergraduate and graduate education", U.S. DEPARTMENT OF EDUCATION, Tech. Rep., 2016.

[3] T. A. Campbell and D. E. Campbell, "Faculty/student mentor program: Effects on academic performance and retention", Research in higher education, vol. 38, no. 6, pp. 727-742, 1997.

[4] S. Feiman-Nemser, Teacher Mentoring: A Critical Review. ERIC, 1996.

[5] B. Bozeman and M. K. Feeney, "Toward a useful theory of mentoring: A conceptual analysis and critique", Administration \& Society, vol. 39, no. 6, pp. 719-739, 2007. 
[6] M. Pita, C. Ramirez, N. Joacin, S. Prentice, and C. Clarke, "Five effective strategies for mentoring undergraduates: Students' perspectives", Council on Undergraduate Research Quarterly, vol. 33, no. 3, pp. 11-16, 2013.

[7] T. S. Barger, "For women engineers, mentoring helps", IEEE Spectrum, vol. 52, no. 9, pp. 27-27, 2015.

[8] E. M. Smith, "Making connections - mentoring program benefits both participants", IEEE Potentials, vol. 26, no. 3, pp. 12-18, 2007.

[9] G. Crisp, V. L. Baker, K. A. Griffin, L. G. Lunsford, and M. J. Pifer, "Mentoring undergraduate students", ASHE Higher Education Report, vol. 43, no. 1, pp. 7-103, 2017.

[10] H. Stoeger, X. Duan, S. Schirner, T. Greindl, and A. Ziegler, "The effectiveness of a one-year online mentoring program for girls in stem", Computers and Education, vol. 69, pp. 408-418, 2013.

[11] J. A. Campbell, C. Aragon, K. Davis, S. Evans, A. Evans, and D. P. Randall, "Thousands of positive reviews: Distributed mentoring in online fan communities", in Proceedings of the ACM Conference on Computer Supported Cooperative Work, CSCW, vol. 27, San Francisco, CA, United states, 2016, pp. 691-704.

[12] L. Dhorne, J.-P. Deflandre, O. Bernaert, S. Bianchi, and M. Thirouard, "Mentoring learners in MOOCs: A new way to improve completion rates?", in Digital Education: Out to the World and Back to the Campus, C. Delgado Kloos, P. Jermann, M. Pérez-Sanagustín, D. T. Seaton, and S. White, Eds. Springer International Publishing, 2017, pp. 29-37.

[13] P. Nuankaew and P. Temdee, "Determining of compatible different attributes for online mentoring model", in 2014 4th International Conference on Wireless Communications, Vehicular Technology, Information Theory and Aerospace Electronic Systems (VITAE), 2014, pp. 1-5.

[14] _ - "Of online community: Identifying mentor and mentee with compatible different attributes and decision tree", in 2015 12th International Conference on Electrical Engineering/Electronics, Computer, Telecommunications and Information Technology (ECTI-CON), 2015, pp. 1-6.

[15] A. M. d. M. R. Reali, R. M. S. P. Tancredi, and M. d. G. N. Mizukami, "Online mentoring as a tool for professional development and change of novice and experienced teachers: A Brazilian experience", in. 2012, pp. 203-218. 